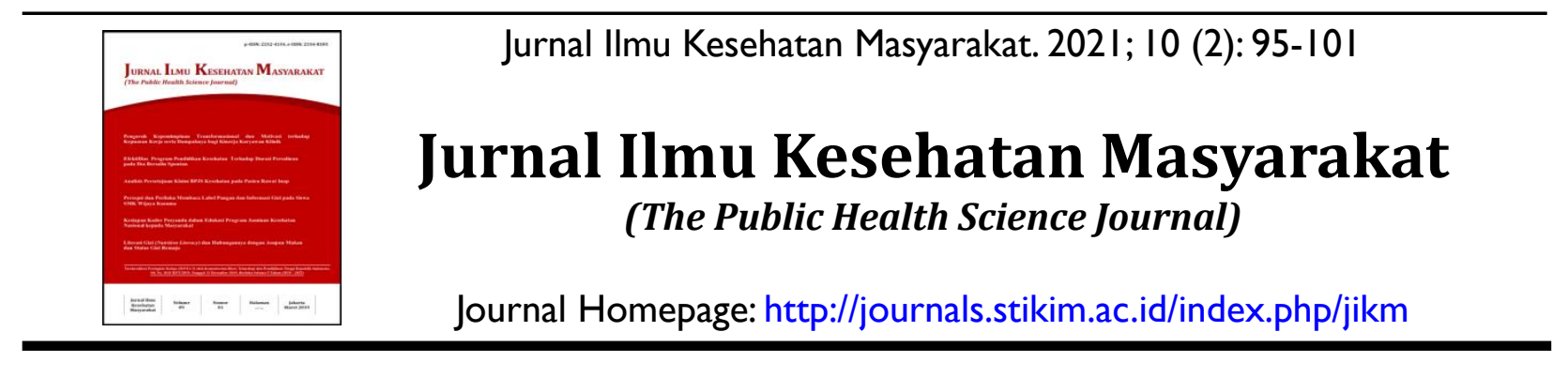

\title{
Pengaruh Edukasi Gizi Terhadap Pengetahuan dan Sikap Ibu dalam Pemenuhan Nutrisi Balita Stunting
}

\author{
Resi Putri Naulia', Hendrawati ${ }^{2}$, La Saudi ${ }^{3}$ \\ 1-3Prodi DIII Keperawatan Politeknik Karya Husada \\ Gedung Atlanta Lt.5 No. 28 Jl. Margonda Raya Pondok Cina Depok, Indonesia \\ Email: resipn15@gmail.com', hendrawatikamil@gmail.com², Odhyaafiyah4@gmail.com³
}

\begin{abstract}
Abstrak
Edukasi gizi bertujuan untuk mengurangi masalah gizi yang ditargetkan pada perubahan pengetahunan, sikap, dan perilaku orangtua berkaitan dengan pemenuhan nutrisi balita. Tujuan penelitian ini untuk mengetahui pengaruh edukasi gizi terhadap pengetahuan dan sikap ibu dalam pemenuhan nutrisi balita stunting. Metode yang digunakan adalah quasi experiment dengan non-equivalent control group design. Sampel dalam penelitian ini adalah 60 ibu yang memiliki balita stunting, yang dibagi dalam kelompok intervensi (KI) dan kelompok kontrol (KK) masing-masing 30 responden. Hasil penelitian menunjukan bahwa terdapat perbedaan bermakna antara pengetahuan $(\mathrm{Pv}=0,005)$ dan sikap ibu dalam pemenuhan nutrisi $(\mathrm{Pv}=0,046)$ sebelum dan setelah edukasi gizi pada KI. Sementara pada KK tidak ditemukan perbedaan bermakna pengetahuan $(\mathrm{Pv}=0,655)$ dan sikap dalam pemenuhan nutrisi $(\mathrm{Pv}=1,000)$. Edukasi gizi pada ibu sangat penting untuk dilakukan untuk meningkatkan pemenuhan nutrisi pada balita.
\end{abstract}

Kata Kunci: Balita, edukasi gizi, stunting.

\begin{abstract}
Nutrition education aims to reduce nutritional problems targeted at changes in annualized, attitudes, and behaviors of parents related to the nutrition of toddlers. This study aims to find out the influence of nutrition education on the knowledge and attitude of mothers in the feeding of nutrition stunting toddlers. The method used quasi experiment with non-equivalentpretest-postest design with control group. Sample is 60 stunting toddler mothers, which were divided into two groups, namely intervention group (IG) and control group (CG) each 30 respondents. The results showed that there is a significant difference between knowledge $(P v=0,005)$ and attitudes in nutrition fulfillment $(P v=0,046)$ before and after nutritional education interventions in IG. While in $C G$ there are no meaningful differences in Knowledge $(P v>0.655)$ and attitude $(P v>1,000)$. Nutrition education is very important to be done to improve the feeding of nutrition in toddlers.
\end{abstract}

Keywords:Toddlers, nutrition education, stunting. 


\section{Pendahuluan}

Sebagian besar intervensi edukasi gizi bertujuan untuk mengurangi masalah gizi yang ditargetkan pada perubahan pengetahunan, sikap, dan perilaku orang tua atau pengasuh berkaitan dengan pemenuhan nutrisi balita. Pendekatan perubahan sikap yang digunakan biasanya berfokus pada orang tua sebagai orang terdekat dalam pemenuhan nutrisi, MPASI, inisiasi menyusu dini (IMD), menyusui sampai 2 tahun, keragaman makanan, pola makan, dan minuman yang dianjurkan.

WHO melaporkan bahwa kurang lebih 59 juta anak di Sub-Sahara Afrika (SSA) menderita beberapa bentuk kekurangan gizi. Di Kenya, tingkat gizi buruk tetap cukup tinggi, sekitar $85 \%$ anak-anak dibawah 5 tahun menderita kekurangan vitamin $\mathrm{A}^{2}$ Kekurangan gizi pada Balita masih menjadi perhatian pemerintah Indonesia. Berdasarkan data Riskesdas 2018, jumlah angka kejadian balita sangat pendek dan pendek sebesar $30,7 \%$ masing-masing sebesar $11,5 \%$ dan $19,2 \%{ }^{3}$. Jumlah tersebut masih di atas toleransi WHO yang menetapkan angka 20\%. Sementara itu, kejadian stunting di DKI Jakarta sebesar $17,7 \%$ dengan angka kasus tertinggi berada di wilayah Kepulauan Seribu (12,8\%), Jakarta Pusat $(2,4 \%)$, Jakarta barat $(0,8 \%)$, Jakarta Utara $(0,7 \%)$, Jakarta Timur $(0,3 \%)$ dan Jakarta Selatan $(0,1 \%){ }^{4}$

Penelitian sebelumnya telah banyak mengkaji pengaruh pengetahuan dan sikap ibu terhadap asupan makan anak-anak, ${ }^{5-6}$ pengetahuan, sikap dan perilaku terhadap pencegahan stunting pada usia balita, ${ }^{7}$ edukasi gizi terhadap peningkatan pengetahuan gizi, sikap dan praktek pada anak sekolah. ${ }^{8}$ Pada penelitian ini kami fokus pada pendidikan gizi untuk meningkatkan pengetahuan dan perubahan sikap pada ibu dalam memenuhi nutrisi pada balita stunting.

\section{Metode}

Penelitian ini merupakan penelitian kuantitatif menggunakan metode quasi experiment dengan non-equivalent control group design. Populasi penelitian adalah semua ibu yang memiliki balita stunting di Jakarta. Sampel penelitian merupakan ibu yang memiliki anak stunting (Z score $\mathrm{PB} / \mathrm{U}$ $<-2$ SD) yang berusia 6-59 bulan, anak tidak mengalami cacat tubuh dan mental, ibu tidak mengalami gangguan pendengaran dan mudah berkomunikasi, bersedia ikut serta sebagai responden penelitian. Kriteria eksklusi responden adalah balita yang mengalami kelainan patologis (down syndrome, kelumpuham) dan sakit kronik (contoh: kanker, gagal ginjal). Pengambilan sampel dalam penelitian ini menggunakan teknik purposive sampling. Perhitungan sampel menggunakan rumus uji hipotesis beda dua mean berpasangan sehingga didapatkan sampel minimal 27 ibu pada tiap kelompok. Peneliti menambahkan $10 \%$ untuk mengantisipasi drop out sehingga jumlah sampel menjadi 30 pada tiap kelompok sehingga total sampel menjadi 60 orang ibu. ${ }^{9-10}$

Penelitian terdiri dari tahap pengumpulan data sebelum intervensi, intervensi dan pengumpulan data setelah intervensi. Pengukuran awal (pre-test) dilakukan pada hari pertama sebelum intervensi kemudian dilanjutkan dengan edukasi gizi pada kelompok intervensi sedangkan pada kelompok kontrol tidak diberikan edukasi gizi. Kelompok intervensi diberikan edukasi gizi dengan metode ceramah, tanya jawab dan demonstrasi. Materi edukasi meliputi nutrisi selama hamil, ASI ekslusif, pedoman gizi seimbang untuk balita, prinsip pemberian makan pada balita, persiapan dan penyimpanan makanan serta penerapan PHBS rumah tangga. Intervensi dilakukan selama 2 hari berturut - turut. Masing-masing pertemuan terdiri dari dua sesi yaitu sesi pertama ceramah dan diskusi kemudian dilanjutkan sesi kedua demontrasi. Tujuh hari setelah intervensi akhir, diberikan post-test. Pada kelompok kontrol post-test diberikan pada hari ketujuh setelah pre-test. Edukasi gizi pada kelompok kontrol dilakukan setelah 
post-test.

Pengumpulan data menggunakan kuesioner modifikasi oleh Mirayanti yang mengacu pada teori Green dan Engel. Kuesioner berisi variabel pola asuh pemenuhan nutrisi dalam keluarga yang dikembangkan dari sub-sub variabel yaitu riwayat pemenuhan nutrisi saat hamil, pemberian ASI ekslusif, persiapan dan penyimpanan makanan, penerapan PHBS rumah tangga, cara komunikasi keluarga terhadap balita dalam pemenuhan nutrisi, peran keluarga dalam mempertahankan asupan gizi keluarga, nilai dan keyakinan keluarga terhadap pola nutrisi dan kemampuan keluarga dalam memilih makanan sehat. Jawaban dari pertanyaan kuesioner adalah pengetahuan dan sikap. Hasil uji validitas pengetahuan 0,469-0,953 dengan reliabilitas 0,982 dan hasil uji validitas sikap adalah 0,448-0,931 dengan reliabilitas $0,973 .^{11}$

Data karakteristik responden dianalisis dengan distribusi frekuensi. Data pengetahuan dilakukan penilaian dan dikategorikan menjadi pengetahuan baik ( $\geq 70 \%$ benar) dan pengetahuan kurang baik $(<70 \%$ benar). Data sikap dilakukan penilaian yang kemudian dikategorikan baik ( $\geq 60,5 /$ median $)$ dan tidak baik ( $<60,5 /$ median). Analisa data menggunakan uji Wilcoxon dan Mann Whitney dengan tingkat signifikansi $\mathrm{p} \leq$ 0,05. Uji Wilcoxon digunakan untuk menganalisis perbedaan pengetahuan dan sikap ibu sebelum dan setelah intervensi pada kedua kelompok. Uji Mann Whitney digunakan untuk menganalisis perbedaan pengetahuan dan sikap setelah intervensi antara kelompok intervensi dan kelompok kontrol. Persyaratan uji Wilcoxon dan uji Mann Withney adalah skala data dalam bentuk skala ordinal.

\section{Hasil Penelitian}

Tabel 1 menunjukkan bahwa mayoritas usia responden pada kedua kelompok berada pada usia dewasa muda yaitu kelompok kontrol sebesar 63,3\% dan kelompok intervensi sebesar $76,7 \%$.
Berdasarkan tingkat pendidikan, sebagian besar ibu pada kelompok kontrol memiliki tingkat pendidikan dasar yaitu sebesar $60 \%$, sedangkan pada kelompok intervensi sebagian besar ibu memiliki tingkat pendidikan menengah yaitu sebesar $56,7 \%$. Berdasarkan penghasilan keluarga, responden mayoritas memiliki penghasilan dibawah UMR yaitu sebesar $80 \%$ pada kelompok kontrol dan $63,3 \%$ pada kelompok intervensi. Status pekerjaan responden mayoritas tidak bekerja yaitu sebesar $86,7 \%$ pada kelompok kontrol dan 90\% pada kelompok intervensi. Mayoritas ibu memiliki anak dengan rentang usia 24-35 bulan yaitu sebesar $50 \%$ pada kelompok kontrol dan sebesar 53,3\% pada kelompok intervensi. Berdasarkan jenis kelamin, mayoritas anak pada kelompok intervensi berjenis kelamin perempuan yaitu sebesar $56,7 \%$ sedangkan pada kelompok kontrol, anak yang berjenis kelamin perempuan sama jumlahnya dengan anak yang berjenis kelamin laki-laki yaitu sebesar $50 \%$. Berdasarkan status gizi (TB/U) mayoritas sangat pendek yaitu pada kelompok kontrol sebesar $60 \%$ dan kelompok intervensi sebesar $66,7 \%$.

Hasil uji Wilcoxon menunjukkan tidak ada perbedaan bermakna antara pengetahuan dan sikap dalam pemberian nutrisi pada kelompok kontrol dengan $\mathrm{p}$ value pengetahuan 0,655 dan sikap 1,000 $(\alpha=0,05)$ sedangkan Pengetahuan dan sikap dalam pemberian nutrisi pada kelompok intervensi menunjukkan perbedaan yang bermakna sebelum dan setelah intervensi dengan pengetahuan $\mathrm{p}=0,000$ dan sikap $p=0,046(\alpha=0,05)$.

Tabel 3 menunjukkan bahwa pada kelompok intervensi, ibu yang memiliki pengetahuan baik dan pola asuh yang baik lebih banyak dibandingkan dengan ibu pada kelompok kontrol. Akan tetapi hasil uji Mann Whitney menunjukkan bahwa tidak ada perbedaan bermakna pengetahuan dan sikap antara kelompok kontrol dengan kelompok intervensi setelah hari ketujuh (post test) dengan nilai $\mathrm{Pv}$ pengetahuan $\mathrm{p}=0,966$ dan sikap $\mathrm{p}=0,110(\alpha=0,05)$. 
Tabel 1. Distribusi Responden Berdasarkan Usia Ibu, Pendidikan Ibu, Penghasilan Keluarga, Pekerjaan Ibu, Usia Anak, Jenis Kelamin Anak dan Status Gizi Anak (n=60)

\begin{tabular}{|c|c|c|c|c|c|}
\hline \multirow[t]{2}{*}{ Variabel } & \multirow[t]{2}{*}{ Kategori } & \multicolumn{2}{|c|}{$\begin{array}{c}\text { Kelompok Kontrol } \\
\text { (KK) }\end{array}$} & \multicolumn{2}{|c|}{$\begin{array}{l}\text { Kelompok Intervensi } \\
\text { (KI) }\end{array}$} \\
\hline & & $\mathrm{n}$ & $\%$ & $\mathrm{n}$ & $\%$ \\
\hline \multirow[t]{2}{*}{ Usia } & Dewasa Muda (18-35 th) & 19 & 63,3 & 23 & 76,7 \\
\hline & Dewasa Tengah ( $>35-55$ th) & 11 & 36,7 & 7 & 23,3 \\
\hline \multirow[t]{3}{*}{ Pendidikan Ibu } & Dasar (SD-SMP) & 18 & 60 & 8 & 26,7 \\
\hline & Menengah (SMÁ) & 11 & 36,7 & 17 & 56,7 \\
\hline & Tinggi (Akademi/PT) & 1 & 3,3 & 5 & 16,6 \\
\hline \multirow[t]{2}{*}{ Penghasilan } & Di bawah UMR & 24 & 80 & 19 & 63,3 \\
\hline & Di atas UMR & 6 & 20 & 11 & 36,7 \\
\hline \multirow[t]{2}{*}{ Pekerjaan } & Tidak Bekerja & 26 & 86,7 & 27 & 90 \\
\hline & Bekerja & 4 & 13,3 & 3 & 10 \\
\hline \multirow[t]{4}{*}{ Usia } & $12-23$ bulan & 6 & 20 & 5 & 16,7 \\
\hline & $24-35$ bulan & 15 & 50 & 16 & 53,3 \\
\hline & $36-47$ bulan & 4 & 13,3 & 3 & 10 \\
\hline & $48-59$ bulan & 5 & 16,7 & 6 & 20 \\
\hline \multirow[t]{2}{*}{ Jenis Kelamin } & Laki-laki & 15 & 50 & 13 & 43,3 \\
\hline & Perempuan & 15 & 50 & 17 & 56,7 \\
\hline \multirow[t]{2}{*}{ Status Gizi (TB/U) } & Pendek & 12 & 40 & 10 & 33,3 \\
\hline & Sangat pendek & 18 & 60 & 20 & 66,7 \\
\hline
\end{tabular}

Tabel 2. Perbedaan Pengetahuan dan Sikap dalam Pemenuhan Nutrisi Sebelum dan Setelah Intervensi Edukasi Gizi pada Kelompok Kontrol dan Kelompok Intervensi (n=60)

\begin{tabular}{|c|c|c|c|c|c|c|c|}
\hline \multirow{2}{*}{ Variabel } & \multirow{2}{*}{ Kelompok } & \multirow{2}{*}{ Kategori } & \multicolumn{2}{|c|}{ Pre-Intervensi } & \multicolumn{2}{|c|}{ Post-Intervensi } & \multirow{2}{*}{ Pvalue } \\
\hline & & & $\mathbf{n}$ & $\%$ & $\mathbf{n}$ & $\%$ & \\
\hline \multirow[t]{4}{*}{ Pengetahuan } & Kontrol & Baik & 3 & 10 & 2 & 6,7 & 0.655 \\
\hline & & Kurang & 27 & 90 & 28 & 93,3 & \\
\hline & Intervensi & Baik & 15 & 59 & 29 & 96,7 & $0.000 *$ \\
\hline & & Kurang & 15 & 50 & 1 & 3,3 & \\
\hline \multirow[t]{4}{*}{ Sikap } & Kontrol & Baik & 16 & 53,3 & 16 & 53,3 & 1.000 \\
\hline & & Tidak Baik & 14 & 46,7 & 14 & 46,7 & \\
\hline & Intervensi & Baik & 10 & 33,3 & 18 & 60 & $0.046^{*}$ \\
\hline & & Tidak Baik & 20 & 66,7 & 12 & 40 & \\
\hline
\end{tabular}

*bermakna pada $\alpha=0,05$

Tabel 3. Perbedaan Pengetahuan dan Sikap dalam Pemenuhan Nutrisi Setelah Intervensi Edukasi Gizi pada Kelompok Kontrol dan Kelompok Intervensi $(n=60)$

\begin{tabular}{|c|c|c|c|c|c|c|}
\hline \multirow{3}{*}{ Variabel } & \multirow{3}{*}{ Kategori } & \multicolumn{4}{|c|}{ Kelompok } & \multirow{3}{*}{ Pvalue } \\
\hline & & \multicolumn{2}{|c|}{ Intervensi } & \multicolumn{2}{|c|}{ Kontrol } & \\
\hline & & $\mathrm{n}$ & $\%$ & $\mathbf{n}$ & $\%$ & \\
\hline \multirow[t]{2}{*}{ Pengetahuan } & Baik & 29 & 96,7 & 2 & 6,7 & \multirow{2}{*}{0,966} \\
\hline & Kurang & 1 & 3,3 & 28 & 93,3 & \\
\hline \multirow[t]{2}{*}{ Sikap } & Baik & 18 & 60 & 16 & 53,3 & \multirow{2}{*}{0,110} \\
\hline & Tidak Baik & 12 & 40 & 14 & 46,7 & \\
\hline
\end{tabular}




\section{Pembahasan}

Stunting dan pemenuhan nutrisi pada balita masih menjadi perhatian utama di Indonesia khususnya di DKI Jakarta. Asupan makanan, sanitasi lingkungan, pemberian makan pendamping, dan pola makan yang buruk menjadi faktor pemicu terjadinya stunting pada balita. ${ }^{12,13}$ Oleh karena itu dalam penelitian ini mengkaji terkait pengaruh edukasi gizi terhadap pengetahuan dan sikap ibu dalam memenuh nutrisi balita stunting. Hasil penelitian menunjukan bahwa pada kelompok intervensi terdapat peningkatan pengetahuan dan perubahan sikap pada ibu balita stunting dalam pemenuhan kebutuhan nutrisi anaknya setelah diberikan edukasi gizi. Sementara pada kelompok kontrol tidak ditemukan perbedaan yang signifikan antara edukasi gizi terhadap pengetahuan dan sikap ibu balita stunting.

Hasil penelitian ini sejalan dengan penelitian Yunitasari, dkk yang menyatakan bahwa terdapat nilai yang signifikan antara pendidikan, brainstorming dan demonstrasi terhadap peningkatan pengetahuan, sikap dan perilaku ibu dalam pencegahan stunting pada kelompok intervensi, sementara pada kelompok kontrol tidak terdapat nilai yang signifikan. $^{7}$ Hasil penelitian ini juga didukung oleh penelitian Maluye, et al yang menunjukkan bahwa tidak terdapat perubahan pengetahuan pada kelompok kontrol. ${ }^{14}$ Efektivitas pendidikan gizi juga sudah diteliti di Kenya bahwa pengetahuan gizi rata-rata signifikan lebih tinggi di kelompok intervensi dari pada kelompok kontrol. ${ }^{15}$ Hal ini sejalan dengan hasil penelitian Mutiso, et al bahwa pendidikan gizi dan faktor psikososial memiliki dampak positif yang kuat sejauh mana penerapan IYCF digunakan. ${ }^{1}$ Penelitian lain dari Ethiopia Selatan menunjukkan bahwa intervensi pendidikan gizi ibu secara signifikaan meningkatkan pengetahuan, sikap, dan praktik ibu dalam penerapan pemberian makan pendamping pada anaknya. $^{16}$

Informasi dalam pendidikan kesehatan dapat mengubah pola pikir menjadi lebih baik sehingga terjadi perubahan sikap. Hal ini sesuai dengan teori yang dikemukan oleh Azwar bahwa pengalaman pribadi, budaya, orang lain, media masa, lembaga atau lembaga keagamaan serta faktor emosional individu merupakan faktor-faktor yang dapat mempengaruhi pembentukan sikap. ${ }^{17}$ Rusmiati dan Hastono mengemukakan bahwa pembentukan sikap diawali dengan pengetahuan yang dipersepsikan sebagai hal yang positif atau negatif, kemudian diinternalisasikan dalam diri seseorang. Selain itu peningkatan sikap positif atau baik ini karena adanya informasi saat memberikan penyuluhan kesehatan yang mengisyaratkan bahwa pemenuhan nutrisi untuk mencegah stunting itu penting. ${ }^{18}$ Hasil penelitian ini menunjukkan pengetahuan dan sikap ibu setelah dilakukan intervensi edukasi gizi meningkat pada kelompok intervensi dibandingkan dengan kelompok kontrol. Artinya edukasi gizi sangat berperan penting dalam peningkatan derajat kesehatan pada individu, kelompok maupun masyarakat terutama dalam mengurangi stunting pada balita.

Kejadian stunting pada balita tentunya tidak hanya karena faktor kurangnya pengetahuan atau sikap ibu yang buruk dalam pemenuhan nutrisi pada anak. Namun faktor tidak langsung (indirect factors) lainnya sangat berperan terjadinya stunting pada balita, diantaranya faktor usia, tangkat pendidikan, penghasilan dan pekerjaan ibu. Dari hasil penelitian ini ditemukan bahwa balita yang mengalami stunting sebagian besar dengan usia ibu dewasa muda antara 18-35 tahun, pendidikan dasar dan menengah, penghasilan dibawah UMR dan ibu yang tidak bekerja. Usia, jenis kelamin, usia balita juga berkontribusi dalam terjadinya stunting. Ibu yang memiliki pendidikan lebih tinggi cenderung memiliki anak dengan gizi yang baik begitu pula sebaliknya. ${ }^{17}$ Beberapa penelitian juga menunjukkan bahwa pendidikan terakhir ibu merupakan salah satu faktor yang mempengaruhi terjadinya stunting. ${ }^{19}$ 


\section{Kesimpulan}

Hasil analisis penelitian ini menunjukkan bahwa edukasi gizi dapat meningkatkan pengetahuan dan sikap dalam pemenuhan nutrisi sehingga nutrisi gizi dapat menjadi salah satu intervensi alternatif untuk meningkatkan perilaku kesehatan dalam mencegah stunting. Penelitian selanjutnya perlu diteliti lebih lanjut mengenai perilaku ibu dalam pemenuhan nutrisi balita setelah mendapatkan edukasi gizi.

\section{Ucapan Terima Kasih}

Ucapan terima kasih kepada Direktorat Riset dan Pengabdian Masyarakat Direktorat Jenderal Riset dan Pengembangan Kementerian Riset, Teknologi dan Pendidikan Tinggi (Ristekdikti) yang telah memberikan Hibah penelitian. Ucapan terima kasih pula pada LLDIKTI dan Direktur Puskesmas Kecamatan Pasar Rebo, Puskesmas Kecamatan Cipayung, Puskesmas Kecamatan Kebayoran Lama dan Puskesmas Kecamatan Pasar Minggu beserta jajaran yang telah memberikan izin dan dukungan sehingga terselengarahnya penelitian ini.

\section{Daftar Pustaka}

1. Mutiso JM, Okello JJ, Lagerkvist CJ, Muoki P, Kosura WO, Heck S. Effect of nutrition education and psychosocial factors on child feeding practices: findings of a field experiment with biofortified foods and different women categories. 2018; 57(4); 346-371.

2. UNICEF. Joint malnutrition country dataset, December 2017. UNICEF, WHO and World. 2017.

3. Riskesdas. Hasil Utama Riskesdas 2018. [Internet]. [diakses 27 Oktober 2020]. https://www.kemkes.go.id/resources/download/i nfo-terkini/hasil-riskesdas-2018.pdf.

4. Portal Statistik Sektor Provinsi DKI Jakarta. Jumlah Balita Kekurangan Gizi. [Internet]. $\begin{array}{llll}\text { [diakses } & 27 & \text { Oktober } & \text { 2020]. }\end{array}$ http://statistik.jakarta.go.id/jumlah-balita-kekura ngan-gizi/.

5. Al-Shookri A, Al-Shukaily L, Hassan F, Al-Sheraji S, Al-Tobi S. Effect of mothers nutritional knowledge and attitudes on Omani children's dietary intake. Oman Medical Journal. 2011; 26 (4); 253-257.
6. Yabancı N, İbrahim Kısaç İ, Karakuş SS. The effects of mother's nutritional knowledge on attitudes and behaviors of children about nutrition. Procedia - Social and Behavioral Sciences. 2014; 116; 4477-4481.

7. Yunitasari E, Rahayu M, Kurniawati ID. The Effects of Lecture, Brainstorming, Demonstration (CBD) to Mother's Knowledge, Attitude, and Behavior About Stunting Prevention on Toddler. Systematic Reviews in Pharmacy. 2020;11(6):1131-1136.

8. Rajikan R, Esmail S. Nutrition Education to Improve Nutrition Knowledge, Attitude and Practice among Yemeni School Children. Trends in Applied Sciences. 2020; 15 (3): 207-213.

9. Lemeshow S, Hosmer Jr DW, Klar J, Lwanga SK. Adequacy of sample size in health studies.WHO. England: John Wiley \& Sons Ltd; 1993

10. Ariawan I. Besar dan metode sampel pada penelitian kesehatan. Jurusan Biostatistik dan Kependudukan. FKM UI; 1998

11. Mirayanti NKA. Hubungan pola asuh pemenuhan nutrisi dalam keluarga dengan status gizi balita di Kelurahan pasir Gunung Selatan Kecamatan Cimanggis Kota Depok. Depok: Universitas Indonesia. [Tidak dipublikasikan]; 2012

12. Badriyah L and Syafiq A. The Association Between Sanitation, Hygiene, and Stunting in Children Under Two-Years (An Analysis of Indonesia's Basic Health Research, 2013). Makara Journal of Health Research.2017:21(2):35-41

13. Beal T, Tumilowicz A, Sutrisna A, Izwardy D, and Neufeld LM. A review of child stunting determinants in Indonesia. Maternal \& Child Nutrition. 2018: 14(4):e12617.https://doi.org/10.1111/mcn,=.126 17

14. Muluye SD, Lemma TB, Diddana TZ. Effects of Nutrition Education on Improving Knowledge and Practice of Complementary Feeding of Mothers with 6- to 23-Month-Old Children in Dlaycare Centers in Hawassa Town, Southern Ethiopia: An Institution-Based Randomized Control Trial. Journal of Nutrition and Metabolism. 2020; (10). https://doi.org/10.1155/2020/6571583

15. Waswa LM, Jordan I, Herrmann J, Krawinkel MB, Keding GB. Community-based educational intervention improved the diversity of complementary diets in western Kenya: results from a randomized controlled trial. Public Health Nutrition. 2015; 18(18); 3406-3419.

16. Demmelash M, CarolJH, Getenesh B, Susan JW. Effectiveness of nutrition education: applying the Health Belief Model in child-feeding practices to use pulses for 
complementary feeding in Southern Ethiopia. Journal Ecology of Food and Nutrition. 2016; 55(3); 308-323.

17. Azwar S. Sikap Manusia Teori dan Pengukurannya. Yogyakarta: Pustaka Pelajar. 2013.

18. Rusmiati D, \& Hastono SP. (2015). Sikap Remaja terhadap Keperawanan dan Perilaku
Seksual dalam Berpacaran. 2015; 10(1). https://doi.org/http://dx.doi.org/10.21109/kesma s.v10i1.815.

19. Scheffler C, Hermanussen M, Bogin B, Liana DS, Taolin F, Cempaka PMVP., ... \& Pulungan A. Stunting is not a synonym of malnutrition. European Journal of Clinical Nutrition. 2019; 10.1038/s41430-019-0439-4. 